\title{
The Role of Islamic Boarding School in Maintaining Physical Fitness of Students (Physical Fitness Study at Huda Mayak Islamic Boarding School, Ponorogo)
}

\author{
Brian Kurniawan Widianto; Agus Kristiyanto; Hanik Liskustyawati \\ Program Studi Ilmu Keolahragaan, Sebelas Maret University of Surakarta, Indonesia
}

http://dx.doi.org/10.18415/ijmmu.v6i4.968

\begin{abstract}
This study aims to determine the physical fitness condition of students in the Darul Huda Mayak Islamic boarding school, Ponorogo. This research uses descriptive method with survey research. The selected sample was 150 students with a purposive sampling technique. Data collection techniques using the Indonesian Physical Fitness Test (TKJI) instrument. Analysis of the data used is in the form of descriptive statistics. The results of this study indicate: the $50 \mathrm{~m}$ run value in the Excellent category is $62.67 \%$ with frequency of 94 students. The hanging up value in the Less category is $20.67 \%$ with frequency of 31 students. The Sit up value in the Moderate category is $36.67 \%$ with frequency of 55 students. The vertical jump value in the Less category is $62.00 \%$ with frequency of 93 students. The 1000 $\mathrm{m}$ run value in the Less category is $53.33 \%$ with frequency of 80 students. The TKJI score in the Medium category is $67.33 \%$ with frequency of 101 students.
\end{abstract}

Keywords: Fitness; Physical; Students; Islamic Boarding School

\section{Introduction}

In Indonesia there are many educational institutions, one of which is Islamic boarding school. Islamic boarding school is a religious education institution that teaches, develops, and disseminates Islamic religious knowledge. This educational institution has long existed in Indonesia and its influence on society, especially in rural areas is very strong. The place functions as a place for mosque to live around the kyai's (teacher) house or mosque (Suryadi, 2018: 265).

Junaedi (2017: 172) states that Islamic boarding schools are educational institutions that have elements: 1) kiai (teacher) as caregivers; 2) students who study Islam; 3) classic books written by earlier ulama (dominies) and in Arabic; 4) teaching system with recitation or madrasa; and 5) huts or dormitories for the residence of the students. Hariadi (2015: 24-25) stated the relationship with the residence of students in the islamic boarding school environment, the students in general are divided into two types, are: (1) mukim santri are students living (boarding) at islamic boarding school and (2) kalong santri are students without staying at islamic boarding school. 
Along with the development of Islamic boarding school also experienced many changes, in addition to studying and deepening religious knowledge Islamic boarding school also added general subjects into the learning curriculum. One of them is physical education which aims to provide opportunities for students to channel their talents in sports, maintain the health of students in order to remain fit and as a means of entertainment for students interrupted a busy schedule of activities.

Physical fitness is the ability and capability of the body to make adjustments to the physical load given to it (from work done daily) without causing significant fatigue (Ministry of Education and Culture, 2017: 6). According to Muhajir and Sutrisno (2014: 125-126) the benefits of physical fitness activities are to lose weight and prevent obesity, prevent heart disease, prevent and regulate diabetes, improve hormone quality, reduce high blood pressure, increase intelligence, provide lots of energy, reduce LDL and increase HDL, reduce symptoms of mild depression and anxiety, reduce the risk of certain cancers, protect from osteoporosis, improve mood, improve self-image and self-confidence, make youthful, make children always active.

Based on observations made by researchers in the Darul Huda Mayak Islamic boarding school, activities and material related to the teaching and learning process and students sports did not display directed activities such as in public schools because in the Darul Huda Mayak boarding school more emphasis on the deepening of religious knowledge, not designed in the school curriculum unit so that the talents and interests and physical development are not channeled into the activity. This is also supported by the lack of a number of competent educators in the sports field. During this time physical fitness activities, especially in research only focused on students and athletes, but in students in boarding schools for measuring physical fitness levels is still a difficult thing to find. The importance of physical fitness for students participants to improve the effectiveness of students learning then physical fitness needs to be improved at all levels of education including at the Darul Huda Mayak boarding school in Ponorogo Regency.

According to Giriwijoyo, et al (2007: 43) there are several other terms that are used for the same purpose as physical fitness, namely: (1) physical fitness, (2) physical ability, (3) physical harmony. A person's activities are dense with various activities both intra and extra. Every activity undertaken requires a high degree of physical fitness. If you do not have good fitness your body will easily feel tired. Besides that, the durability is easily decreased so that it is susceptible to disease. The degree of one's physical fitness greatly determines his physical abilities in carrying out his daily tasks. The higher the degree of physical fitness of a person the higher the ability of his physical work. Every person who has good physical fitness will easily do a variety of activities without feeling tired and not easily attacked by diseases.

\section{Research Methods}

This study uses descriptive methods, while the form of this study is a survey. As for the population of this study were students of Darul Huda Mayak Islamic boarding school, Ponorogo. The sample in this study were 150 students. The sampling technique used is using purposive sampling technique which is a sampling technique with certain considerations (Sugiyono, 2016: 79). These considerations include several criteria, including males students aged 13-15 years and students living (boarding) at islamic boarding school.

Data collection techniques used in this study used a direct treatment test on the students of the Darul Huda Mayak boarding school, Ponorogo by using the Indonesian Physical Fitness Test (TKJI) instrument in the age group 13-15 years. The TKJI is based on the 5 Fit and Healthy module published by 
the Ministry of Culture (2017: 26) for children aged 13-15 years including: 50 meters run, hanging up for 60 seconds, sitting up (sit up) for 60 seconds, vertical jump, and 1000 meters run.

Analysis of the data used in the form of descriptive statistics with the following formula:

$$
\begin{aligned}
& D p=\frac{n}{N} \times 100 \% \\
& \text { Dp }=\text { descriptive percentage } \\
& n \quad=\text { the number of values obtained } \\
& \mathrm{N} \quad=\text { total value }
\end{aligned}
$$

\section{Results And Discussion}

Presentation of data in research obtained from 150 male students aged 13-15 years at the Darul Huda Mayak Islamic boarding school, Ponorogo relating to physical fitness. Based on the descriptive analysis carried out presented in table 1 as follows:

Table 1. Physical Fitness Students of Islamic Boarding School Darul Huda Mayak, Ponorogo Ages 13-15 Years Old

\begin{tabular}{lccccc}
\hline \multicolumn{1}{c}{ Indicator } & $\mathrm{N}$ & Min & Max & Averages & Std. Deviation \\
\hline 50 m run & 150 & 2 & 5 & 4.47 & 0.766 \\
Hanging up & 150 & 1 & 4 & 1.40 & 0.676 \\
Sit up & 150 & 1 & 5 & 3.61 & 0.940 \\
Vertical jump & 150 & 1 & 5 & 2.21 & 0.726 \\
1000 m run & 150 & 1 & 3 & 1.72 & 0.687 \\
TKJI & 150 & 8 & 19 & 13.41 & 1.799 \\
\hline
\end{tabular}

The description of the research data is in table 1 the physical fitness value of male students of the 13-15 year old Darul Huda Mayak Islamic boarding school which consists of 150 samples, so the value for the $50 \mathrm{~m}$ run are a minimum score is 2 , a maximum score is 5 , an average of 4.47 and the standard deviation is 0.766 . Hanging up are a minimum score is 1 , a maximum score is 4 , an average is 1.40 and a standard deviation is 0.676 . The value of sit up are a minimum score is 1 , a maximum score is 5 , an average is 3.61 and a standard deviation is 0.940 . The vertical jump value are a minimum score is 1 , a maximum score is 5 , an average is 2.21 and a standard deviation is 0.726 . The value of $1000 \mathrm{~m}$ run are a minimum score is 1 , a maximum score is 3 , the average result is 1.72 and the standard deviation is 0.687 . TKJI value are a minimum score is 8 , a maximum score is 19 , an average is 13.41 and a standard deviation is 1.799 .

Based on the research data obtained, the physical fitness results of the male students of the Darul Huda Mayak Islamic Boarding School aged 13-15 years are as follows:

a) $50 \mathrm{~m}$ run, based on the percentage analysis conducted, the $50 \mathrm{~m}$ run test scores are presented in table 2 as follows: 
Table 2. Percentage of $50 \mathrm{~m}$ Run Test Scores for Males Students of Pondok Darul Huda Mayak Islamic Boarding School Age 13-15 years

\begin{tabular}{cclcc}
\hline No & Value of 50 m run test & Classfication & Frequency & Percentage \\
\hline 1 & 5 & Excellent & 94 & $62.67 \%$ \\
2 & 4 & Good & 35 & $23.33 \%$ \\
3 & 3 & Moderate & 19 & $12.67 \%$ \\
4 & 2 & Less & 2 & $1.33 \%$ \\
5 & 1 & Very Little & 0 & $0.00 \%$ \\
\hline \multicolumn{7}{r}{ Total } & & 150 \\
\hline
\end{tabular}

Based on the data in table 2, it is presented in graphical form in Figure 1 below

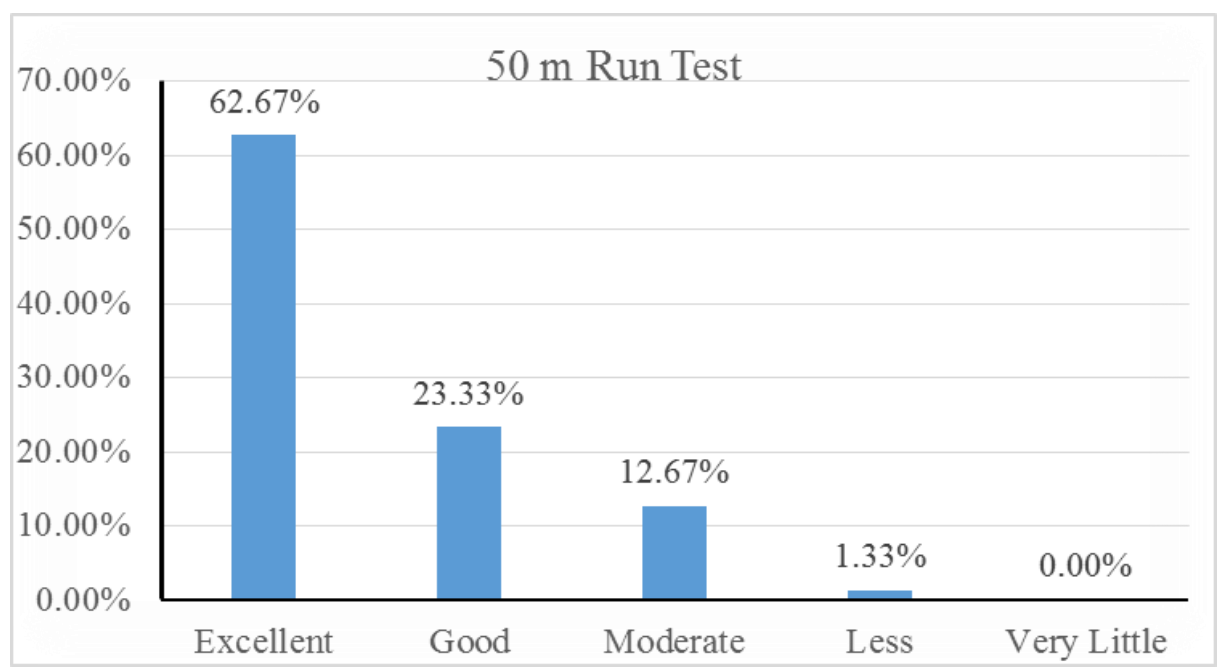

Figure 1. Graph of Percentage Score of $50 \mathrm{~m}$ Run Test for Male Students of Darul Huda Mayak Islamic Boarding School Age 13-15 years

Based on the data in table 2 and figure 1, the value for $50 \mathrm{~m}$ run is obtained, are the value with Excellent category is $62.67 \%$ with a frequency of 94 students. The Good category is $23.33 \%$ with a frequency of 35 students. Medium category is $12.67 \%$ with a frequency of 19 students. The Less category is $1.33 \%$ with a frequency of 2 students. Very little category $0.00 \%$ with a frequency of 0 students.

b) Hanging up, based on the percentage analysis conducted, the body lift test value is presented in table 3 as follows:

Table 3. Percentage of Hanging Up Values Males Students of Darul Huda Mayak Islamic Boarding School Ages 13-15 years

\begin{tabular}{cclcc}
\hline No & Value of hanging up test & Classfication & Frequency & Percentage \\
\hline 1 & 5 & Excellent & 0 & $0.00 \%$ \\
2 & 4 & Good & 1 & $0.67 \%$ \\
3 & 3 & Moderate & 13 & $8.67 \%$ \\
4 & 2 & Less & 31 & $20.67 \%$ \\
5 & 1 & Very Little & 105 & $70.00 \%$ \\
\hline \multicolumn{5}{c}{ Total } \\
\hline
\end{tabular}

Based on the data in table 3, it is presented in graphical form in Figure 2 below. 


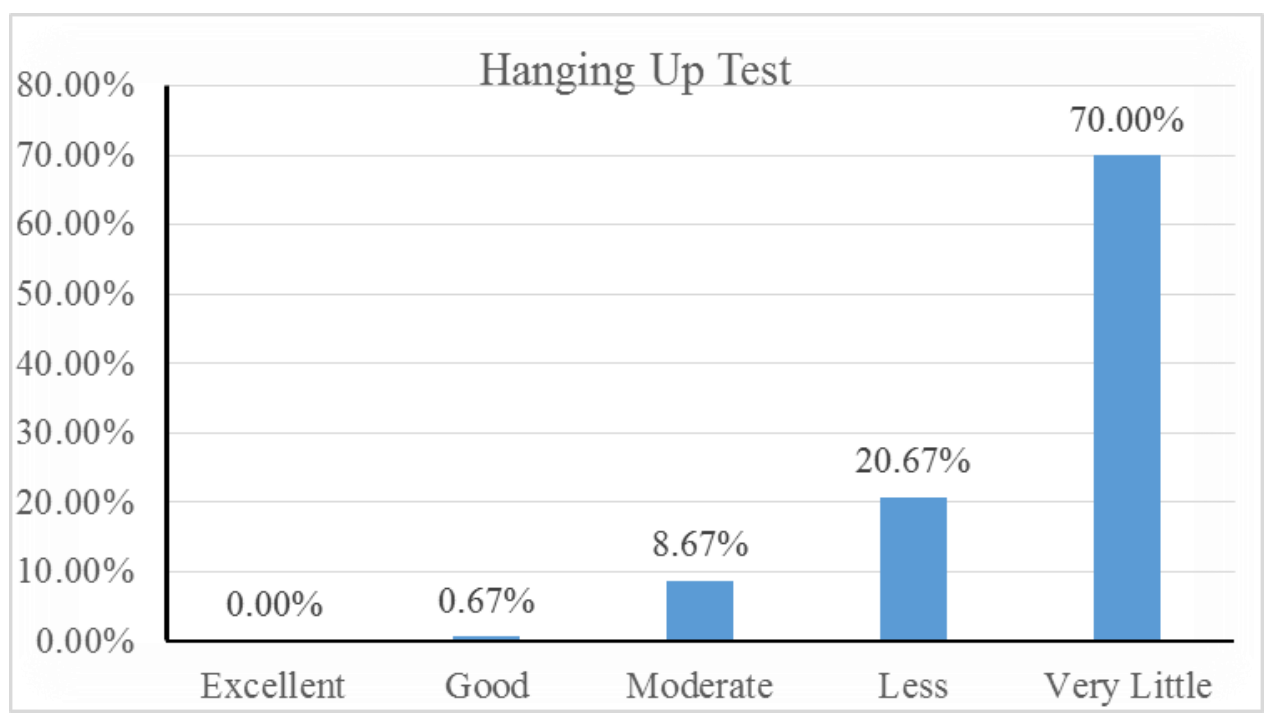

Figure 2. Graph of Hanging Up Percentage Score of Male Students of Darul Huda Mayak Islamic Boarding School Ages 13-15 years old

Based on the data in table 3 and figure 2, the value for Hanging Up test is obtained, the value in the Excellent category is $0 \%$ with a frequency of 0 student. The Good category is $0.67 \%$ with a frequency of 1 student. The Medium category is $8.67 \%$ with a frequency of 13 students. The Less category is $20.67 \%$ with a frequency of 31 students. The Very Little is $70.00 \%$ with a frequency of 105 students.

c) Sit up, based on the percentage analysis carried out, the value of the Sit up test is presented in table 4 as follows:

Table 4. Percentage of Sit Up Values Males Students of Darul Huda Mayak Islamic Boarding School Ages 1315 years

\begin{tabular}{cclcc}
\hline No & Value of sit up test & Classfication & Frequency & Percentage \\
\hline 1 & 5 & Excellent & 28 & $18.67 \%$ \\
2 & 4 & Good & 53 & $35.33 \%$ \\
3 & 3 & Moderate & 55 & $36.67 \%$ \\
4 & 2 & Less & 11 & $7.33 \%$ \\
5 & 1 & Very Little & 3 & $2.00 \%$ \\
\hline \multicolumn{2}{r}{ Total } & & 150 \\
\hline
\end{tabular}

Based on the data in Table 4, it is presented in graphical form in Figure 3 below. 


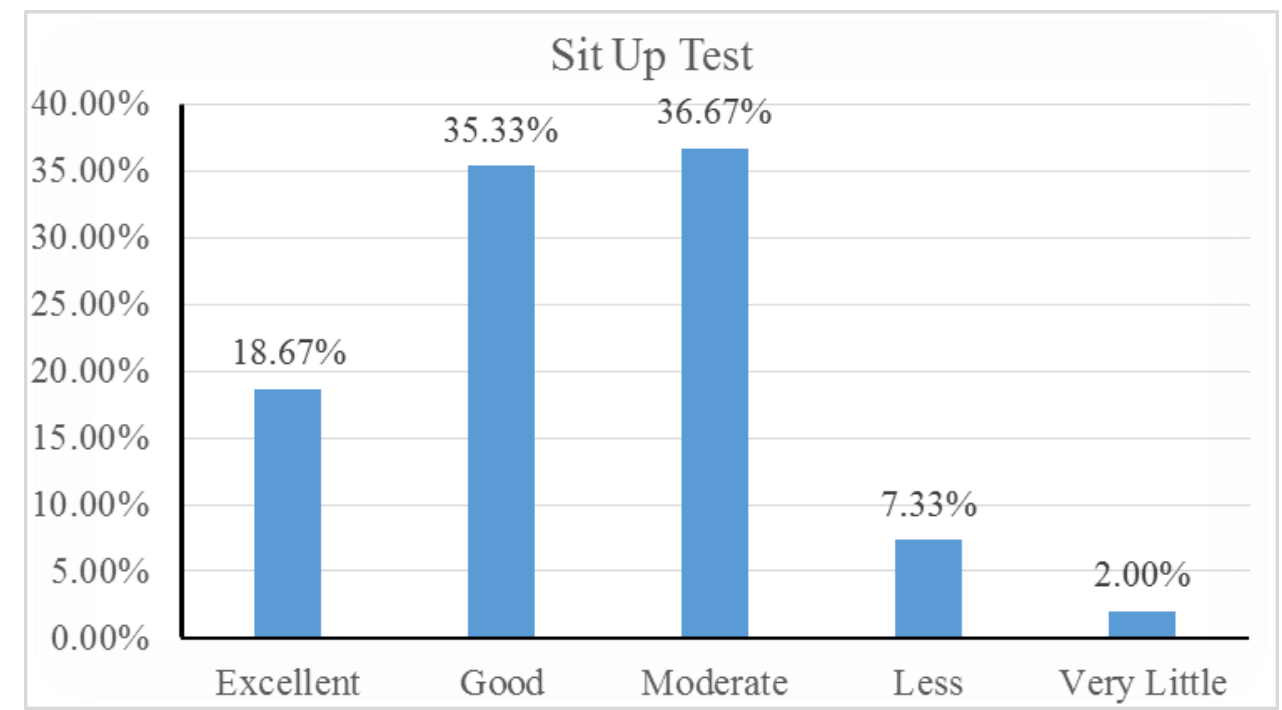

Figure 3. Graph of Sit Up Percentage Score of Male Students of Darul Huda Mayak Islamic Boarding School Ages 13-15 years old

Based on the data in table 4 and figure 3, the value for Sit up is obtained, in the Excellent category value of $18.67 \%$ with a frequency of 28 students. The Good category is $35.33 \%$ with a frequency of 53 students. The Medium category is $36.67 \%$ with a frequency of 55 students. The Less category is $7.33 \%$ with a frequency of 11 students. Very Little category $2.00 \%$ with a frequency of 3 students.

d) Vertical Jump, based on the percentage analysis conducted obtained the Vertical Jump test value is presented in table 5 as follows:

Table 5. Percentage of Vertical Jump Values Males Students of Darul Huda Mayak Islamic Boarding School Ages 13-15 years

\begin{tabular}{cclcc}
\hline No & Value of vertical jump test & Classfication & Frequency & Percentage \\
\hline 1 & 5 & Excellent & 2 & $1.33 \%$ \\
2 & 4 & Good & 4 & $2.67 \%$ \\
3 & 3 & Moderate & 34 & $22.67 \%$ \\
4 & 2 & Less & 93 & $62.00 \%$ \\
5 & 1 & Very Little & 17 & $11.33 \%$ \\
\hline \multicolumn{2}{c}{ Total } & & 150 & \\
\hline
\end{tabular}

Based on the data in Table 5, it is presented in graphical form in Figure 4 below. 


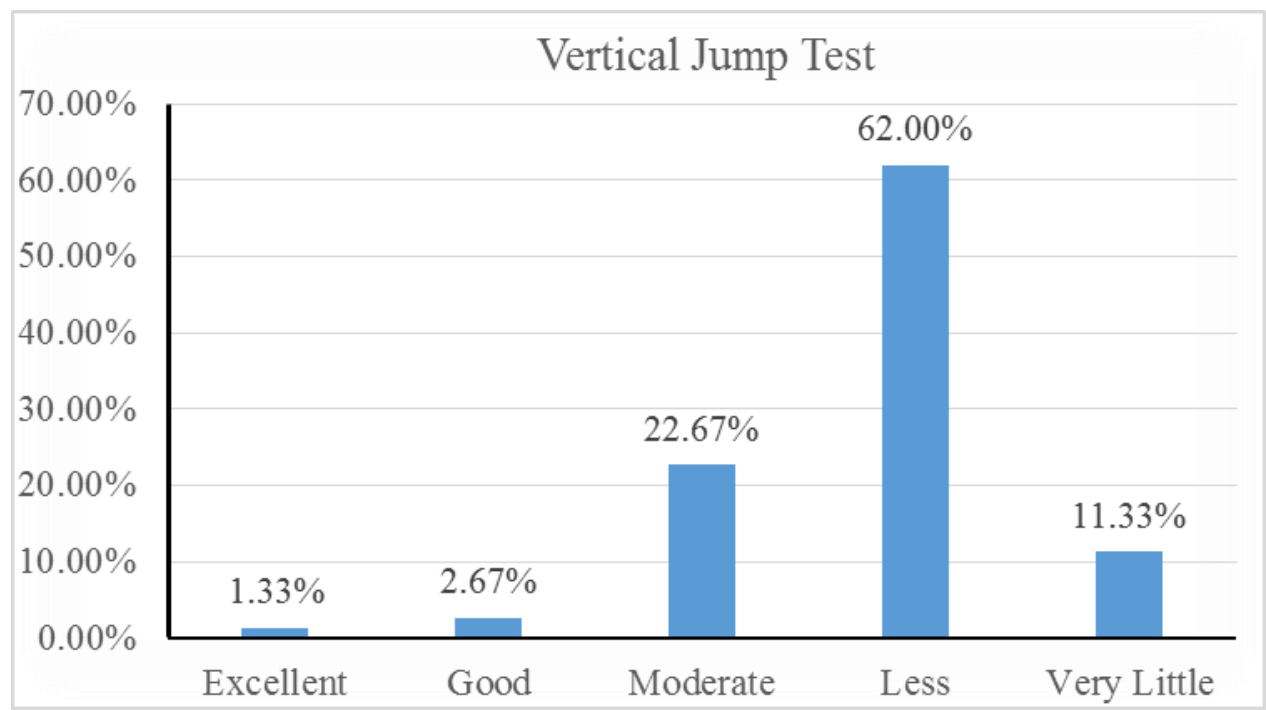

Figure 4. Graph of Vertical Jump Percentage Score of Male Students of Darul Huda Mayak Islamic Boarding School Ages 13-15 years old

Based on the data in Table 5 and Figure 4, the value of Vertical Jump is obtained, in the Excellent category value of $1.33 \%$ with a frequency of 2 students. The Good category is $2.67 \%$ with a frequency of 4 students. Medium category is $22.67 \%$ with a frequency of 34 students. The Less category is $62.00 \%$ with a frequency of 93 students. The Very Little category is $11.33 \%$ with a frequency of 17 students.

e) $1000 \mathrm{~m}$ run, based on the percentage analysis carried out, the value of $1000 \mathrm{~m}$ run test is presented in table 6 as follows:

Table 6. Percentage of $1000 \mathrm{~m}$ Run Values Males Students of Darul Huda Mayak Islamic Boarding School Ages 13-15 years

\begin{tabular}{cclcc}
\hline No & Value of 1000 m run test & Classfication & Frequency & Percentage \\
\hline 1 & 5 & Excellent & 0 & $0.00 \%$ \\
2 & 4 & Good & 4 & $2.67 \%$ \\
3 & 3 & Moderate & 8 & $5.33 \%$ \\
4 & 2 & Less & 80 & $53.33 \%$ \\
5 & 1 & Very Little & 58 & $38.67 \%$ \\
\hline \multicolumn{2}{c}{ Total } & & 150 & \\
\hline
\end{tabular}

Based on the data in Table 6, it is presented in graphical form in Figure 5 below. 


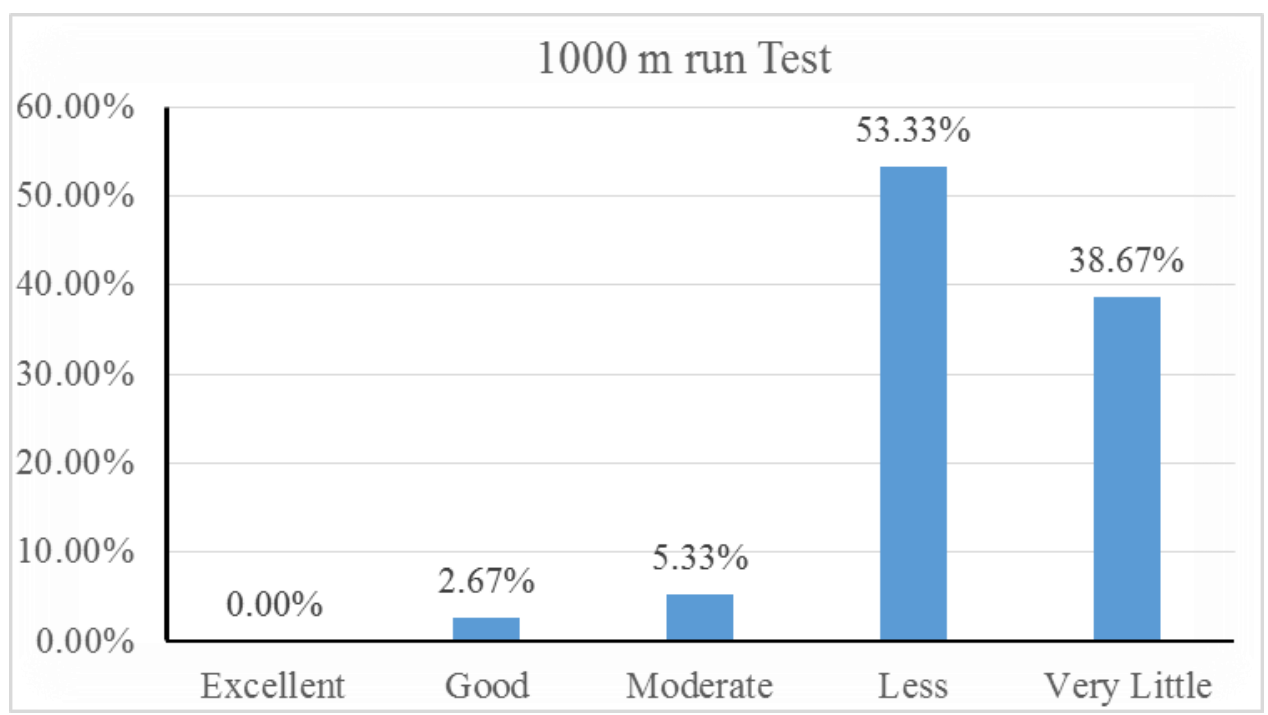

Figure 5. Graph of $1000 \mathrm{~m}$ Run Percentage Score of Male Students of Darul Huda Mayak Islamic Boarding School Ages 13-15 years old

Based on the data in Table 6 and Figure 5, the value for $1000 \mathrm{~m}$ run test is obtained, the value in the Excellent category is $0 \%$ with a frequency of 0 student. The Good category is $2.67 \%$ with a frequency of 4 students. Medium category is 5.33\% with a frequency of 8 students. The Less category is 53.33\% with a frequency of 80 students. The Very Little category is $38.67 \%$ with a frequency of 58 students.

Based on the percentage analysis, the overall value of TKJI is presented in table 7 as follows:

Table 7. Overall TKJI Scores

\begin{tabular}{cclcc}
\hline No & Value of TKJI & Classfication & Frequency & Percentage \\
\hline 1 & $22-25$ & Excellent & 0 & $0.00 \%$ \\
2 & $18-21$ & Good & 3 & $2.67 \%$ \\
3 & $14-17$ & Moderate & 101 & $67.33 \%$ \\
4 & $10-13$ & Less & 44 & $29.33 \%$ \\
5 & $5-9$ & Very Little & 1 & $0.67 \%$ \\
\hline \multicolumn{5}{c}{ Total } \\
\hline
\end{tabular}

Based on the data in Table 7, it is presented in graphical form in Figure 6 below. 


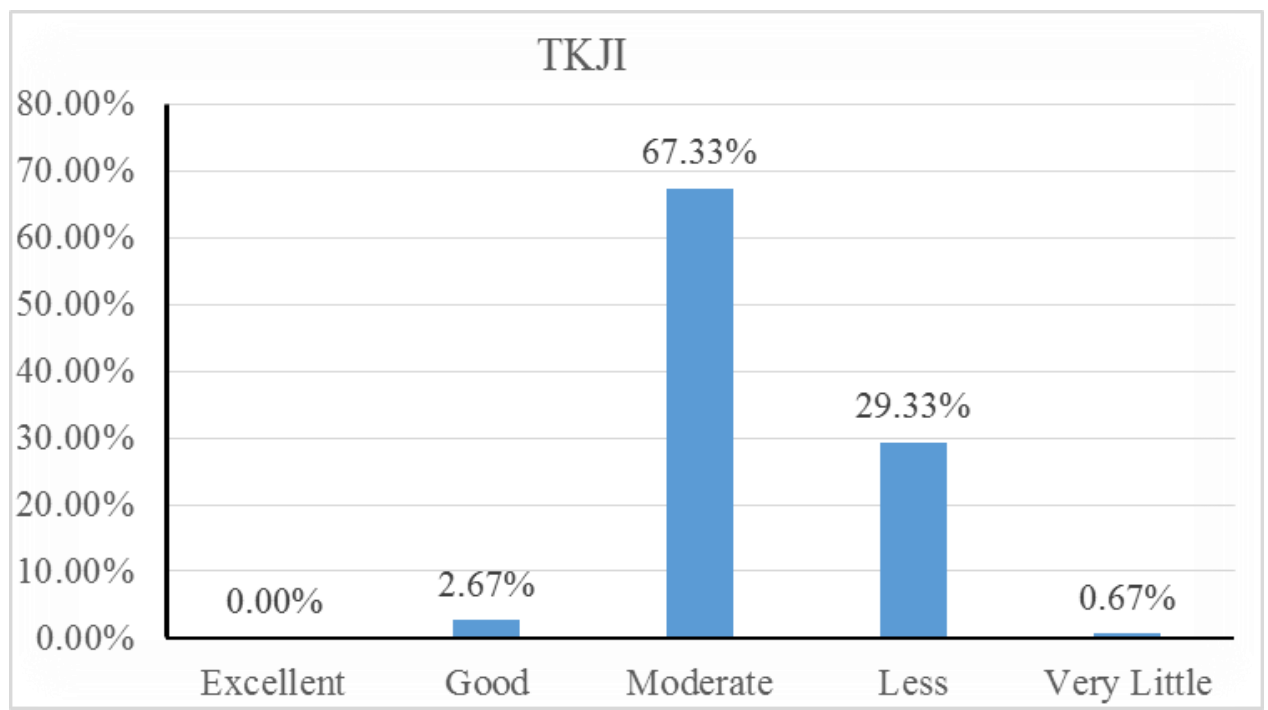

Figure 6. Graph of TKJI Percentage Score of Male Students of Darul Huda Mayak Islamic Boarding School Ages 13-15 years old

Based on the data in Table 7 and Figure 6, the value obtained for TKJI is the value in the Excellent category is $0 \%$ with a frequency of 0 student. The Good category is $2.67 \%$ with a frequency of 4 students. The Medium category is $67.33 \%$ with a frequency of 101 students. The Less category is $29.33 \%$ with a frequency of 44 students. Very Little category $0.67 \%$ with a frequency of 1 student.

The findings of the above research show that the fitness of the male Students of Darul Huda Mayak Islamic Boarding School Ages 13-15 years according to the TKJI test in the Medium category are 101 students with a percentage of $67.33 \%$. The test results came from 5 types of tests, are $50 \mathrm{~m}$ run, hanging up, Sit up, Vertical jump, and $1000 \mathrm{~m}$ run.

The results were supported by the results of interviews with several students who stated that their daily activities emphasized more on deepening religion. Physical fitness activities are only in the form of morning exercise which is usually done on Friday. These conditions are factors that affect the results of physical fitness tests of students. In connection with the results of fitness on the students results in activities carried out daily students. This is in line with research from Sharma et al. (2018) that physical activity enhances mental health and is important for optimal health and function of muscles, bones, and joints. Physical activity can improve healthy cognitive and psychosocial functions. The higher the amount of physical activity, the greater the health benefits. In addition, there is a decrease in mental stress levels with regular exercise. Because physical activity and mental stress are factors that influence physical fitness.

Cruzado et al. (2017) in their study also showed differences in physical fitness between people who do physical activity and those who don't practice physical activity, where physical fitness performance is better in physically active people. Based on the results of the students fitness test, it appears that the efforts of Islamic boarding schools in maintaining the fitness of the students are still lacking. Darmawan (2017) provides a solution in maintaining students' physical fitness. There are two solutions as a teacher's effort to improve students' physical fitness, are by modifying the time of physical education lesson hours and the second solution is by increasing the physical education teacher's strategy in designing learning using the new paradigm of physical education (fun, busy, integral, modification). 


\section{Conclusion}

Based on the results of the study, it can be concluded that the results of the research conducted are as follows: the value of $50 \mathrm{~m}$ run in the Excellent categories is $62.67 \%$ with a frequency of 94 students. The hanging up value in the Less category is $20.67 \%$ with a frequency of 31 students. The Sit up value in the Moderate category is $36.67 \%$ with a frequency of 55 students. The value of the vertical jump in the Less category is $62.00 \%$ with a frequency of 93 students. The $1000 \mathrm{~m}$ run value in the Less category is $53.33 \%$ with a frequency of 80 students. The TKJI score in the Medium category is $67.33 \%$ with a frequency of 101 students.

\section{References}

Cruzado, D.P., Vargas, A.I.C., Garcia, E.V., \& Cleries, F.M. (2017). Physical fitness and levels of physical activity in people with severe mental illness: a cross-sectional study. BMC Sports Science, Medicine and Rehabilitation, Vol. 9, No. 17, pp. 1-6.

Darmawan, I.( 2017). Upaya Meningkatkan Kebugaran Jasmani Siswa Melalui Penjas. Prosiding Seminar Nasional Profesionalisme Tenaga Profesi PJOK, Universitas Negeri Malang.

Giriwijoyo, S., Komariyah, L., dan Kartinah, N.T. (2007). Ilmu Kesehatan Olahraga Untuk Kesehatan dan Untuk Prestasi Olahraga. Bandung: Fakultas Pendidikan Olahraga dan Kesehatan UPI.

Hariadi. (2015). Evolusi Pesantren: Studi Kepemimpinan Kiai Berbasis Orientasi ESQ. Yogyakarta: LKiS Yogyakarta.

Junaedi, M. (2017). Paradigma Baru Filsafat Pendidikan Islam. Jakarta: Kencana.

Ministry of Education and Culture. (2017). Modul 5: Bugar dan Sehat Olahraga dan Rekreasi Paket B Setara SMP/MTs. Jakarta: Kementerian Pendidikan dan Kebudayaan Direktorat Jenderal Pendidikan Anak Usia Dini dan Pendidikan Masyarakat Direktorat Pembinaan Pendidikan Keaksaraan dan Keseteraan.

Muhajir, dan Budi, S. 2013. Pendidikan Jasmani, Olahraga, dan KesehatanKelas VII. Jakarta: Politeknik Negeri Media Kreatif.

Sharma, P., Sharma, R., Choudhary, A., Vats, H., Kataria, J., \& Asif, M. (2018). Assessment of level of physical fitness and level of mental stress in exercising and non-exercising physiotherapy students. International Journal of Yoga, Physiotherapy and Physical Education, Vol. 3, Issue 5, pp. 12-16.

Sugiyono. (2016). Metode Penelitian Kuantitatif, Kualitatif dan R\&D. Bandung: Alfabeta.

Suryadi, R.A. (2018). Ilmu Pendidikan Islam. Yogyakarta: Deepublish.

\section{Copyrights}

Copyright for this article is retained by the author(s), with first publication rights granted to the journal. This is an open-access article distributed under the terms and conditions of the Creative Commons Attribution license (http://creativecommons.org/licenses/by/4.0/). 